\title{
THE TRUE MEANING OF FORCE—A REPLY TO MARY ELLEN O’CONNELL
}

\author{
Tom Ruys*
}

\section{Of Trojan Horses and Pandora's Boxes}

In her comment ${ }^{1}$ on my piece ${ }^{2}$ in the latest issue of the American Journal of International Law (The Meaning of "Force" and the Boundaries of the Jus ad Bellum: Are "Minimal" Uses of Force Excluded from UN Charter Article 2(4)?), Mary Ellen O'Connell expresses strong objections to the piece's central thesis, notably that small-scale or "targeted" forcible acts are not as such excluded from the scope of the prohibition on the use of force in UN Charter Article 2(4). What is more, she sees the central thesis and narrative of the piece as a mere veil, behind which hides the true aim of the article, notably to set forth an extensive reading of the right of selfdefense-which was allegedly also the point of my book ${ }^{3}$ on armed attack of 2010. In other words, an argument pleading for a broad interpretation of the prohibition on the use of force is in reality used as a Trojan horse, to lure the unsuspecting reader into accepting a broader right of states to use force, doing considerable damage to the Charter regime on the use of force.

Mary Ellen O'Connell misreads the piece's purpose. There is indeed no hidden agenda underlying the analysis. The article is effectively concerned with the interpretation of UN Charter Article 2(4) - although it is hard to deal with this topic without saying anything on the cases in which force can or cannot be used.

The inspiration for the article was essentially twofold. First, it struck me that the argument that minimal uses of force are excluded from Article 2(4) appears to be gaining ground (as is evident from the inclusion of the argument in the report of the Independent International Mission on the Conflict in Georgia). Yet, as Corten has observed, ${ }^{4}$ there is scant in-depth analysis of the type of acts that are covered by Article 2(4). Corten's detailed analysis of customary practice relating to Article 2(4) (arguably the first of its kind) reveals that there is a fair amount of practice supporting this position-as does O'Connell's own research. At the same time, my feeling was that the cited practice was often ambiguous and that relevant counter-evidence was not properly addressed. What is more, I had difficulties with some of the theoretical arguments set forth by both authors, including, for instance, the implicit suggestion that a targeted operation abroad crosses the threshold of Article 2(4) when it results in fighting on the ground, but remains below the threshold when the target(s) are eliminated without giving rise to further exchanges of fire (e.g., because the territorial state is unaware, or decides to stand by) - this is an argument that to some extent puts the cart before the horse. In addition, I found it surprising that it is precisely two authors who are sometimes labeled as "restrictionists"-

\footnotetext{
* Assistant Professor of International Law at University of Ghent.

Originally published online 3 Sept. 2014.

${ }^{1}$ Mary Ellen O'Connell, The True Meaning of Force, 108 AJIL Unbound 141 (2014).

2 Tom Ruys, The Meaning of "Force" and the Boundaries of the Jus Ad Bellum: Are "Minimal Uses of Force Excluded From UN Charter Article 2(4)?, 108 AJIL 159 (2014).

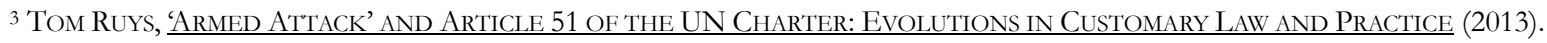

${ }^{4}$ Olivier Corten, The LaW Against War 51 (2010).
}

ASIL and Tom Ruys (C) 2014 
and both of whom I hold in high esteem - that should be the staunchest supporters of a narrow reading of Article 2(4).

Second, my attention was drawn to the possible risks that come with excluding small-scale and targeted operations from UN Charter Article 2(4). Indeed, the de minimis argument, at least potentially, opens the door to the invocation of various grounds precluding wrongfulness (countermeasures, distress, and necessity) to justify forcible acts that allegedly remain below the threshold of Article 2(4). O'Connell's comment reveals that this concern is not baseless. Indeed, with reference to the apprehension of Abu Khattala in Benghazi in 2014, O'Connell makes the argument that forcible abductions of individuals abroad can be justified as lawful countermeasures, for instance, when the territorial state has failed to try or extradite persons suspected of certain crimes, or when it has failed to undertake diligent efforts to arrest a person. Excuse me? Should we conclude that the members of the Security Council had it wrong when they found the Eichmann abduction to be a violation of the UN Charter? Should Belgium have forcibly airlifted Hissène Habré from Senegal instead of having the latter country condemned by the International Court of Justice for breaching the aut dedere, aut judicare rule? To the present author's knowledge, there is no opinio juris to support the view that forcible abductions of individuals from another country can be justified as lawful countermeasures (let alone that I should hold the view that such operations can simply be regarded as a form of self-defense as O'Connell mistakenly suggests).

Furthermore, the slippery slope upon which O'Connell embarks does not stop at forcible abductions. Indeed, according to O'Connell, assassinations by "poisoning, knifing, or shooting an individual" abroad all remain ipso facto below the Article 2(4) threshold. By contrast, the launching of "multiple tank-killing Hellfire missiles from a drone at a group of people" is regarded as coming within the ambit of Article 2(4). What, then, about a single missile fired by a drone against a single suspected terrorist driving his jeep in some far-off desert? If we accept that the latter scenario remains below the Article 2(4) threshold and that human rights law does not (yet?) apply extraterritorially to this type of drone operations (which is admittedly a subject of discussion), or, alternatively, that resort to lethal force in such setting can constitute a 'last resort' compatible with human rights law, then again trigger-happy states can all too easily draw the countermeasures card.

To conclude, while O'Connell claims that my position is somehow aimed at expanding the right to resort to force in self-defense, it is perhaps rather her own position in support of a de minimis threshold that causes damage to the Charter regime on the use of force and, more generally, carries the risk of jeopardizing international peace and security.

\section{The de minimis threshold}

A few more words on the subject of the meaning of force in Article 2(4). As O'Connell points out in her comment, I readily concede that there is a fair amount of state practice that can be interpreted as rendering support to the idea of a de minimis threshold for Article 2(4). This evidence should not be passed over lightly, and both O'Connell and Corten have done an excellent job in identifying various relevant precedents. Yet, even if it would be absurd to bring some situations within the scope of Article 2(4) (e.g., a bar fight between (uniformed) British and U.S. troops stationed in Afghanistan), I believe the case against completely excluding minor uses of armed force is stronger - this is ostensibly a point where we must agree to disagree.

Without revisiting the evidence and counter-evidence at length, let me restrict myself to a few reactions.

First, O'Connell refers to the fact that the drafters of the UN Charter chose to exclude economic force from the scope of Article 2(4). I fail to see how this renders support to the view that the drafters of the Charter were only concerned with grave uses of force, rather than with all uses of armed force. 
Second, O'Connell observes that in some instances where states invoke the language of "force," "aggression" or "Article 2(4)," they do so rhetorically and "not as a serious legal claim." My view is that instances where states (or international organizations) do invoke such language normally carry greater weight in terms of clarifying the law, than instances where states abstain from referring to it. Indeed, a state that refrains from invoking this language may be motivated by various political or practical reasons (e.g., a desire not to let an incident escalate diplomatically), whereas actual references to the aforementioned terms are prima facie indicative of the state's opinio juris.

Third, O'Connell notes that some of the cases of low-level force that have been treated as Article 2(4) violations are ambiguous. This is true- -just as much as it is true for cases that seemingly render support to the idea of a de minimis threshold. Analyzing customary practice is not a matter of exact science. Still, the claim that the weight of the evidence is heavily in favor of a de minimis threshold does not hold. The 1988 assassination of Khalil al-Wazir by Israeli commandos in Tunis is a good example. In spite of the "extremely limited" (dixit Corten) nature of the operation-Israeli commandos killed four persons, including al-Wazir-the Security Council condemned "the aggression ... against the sovereignty and territorial integrity of Tunisia in flagrant violation of the Charter of the United Nations." The preamble of the resolution ${ }^{5}$ moreover explicitly refers to Article 2(4). Is this ambiguous practice?

Fourth, the suggestion that numerous others have agreed that "minor" uses of armed force, including targeted killings, remain outside Article 2(4) must be put into perspective. In his book on Targeted Killing (2008), for instance, Melzer asserts that "[a]uthors generally agree that, in principle, the resort by a state to targeted killings within another state falls under the prohibition on interstate force expressed in Article 2(4) UN Charter."'

In all, (1) customary practice (even if not always clear-cut) does not render convincing support to the existence of a de minimis threshold; (2) the acceptance of such de minimis threshold risks opening Pandora's box (for the reasons set out above); and (3) a broad interpretation of Article 2(4) is conceptually more convincing. Let us briefly turn to this last point.

\section{Conceptually Making Sense of Lanful Uses of Armed Force}

As mentioned above, O'Connell reads the article as a veiled attempt to set forth an expansive reading of the right of self-defense. Upon closer reading, however, our respective positions on the situations where states may lawfully resort to armed force are far less apart than she seems to believe. More generally, there is far broader agreement among scholars as to when states may use armed force to oppose trespassing troops or military aircraft, or in the context of hostile encounters between military aircraft or vessels on the high seas, than is sometimes acknowledged (key in such scenarios is that recourse to force is a last resort, and abides in the strictest manner with the necessity and proportionality criteria in order to avert any escalation). What authors do disagree on, however, is primarily the legal basis for such forcible responses.

Those accepting a de minimis threshold for Article 2(4) necessarily seek the legal basis for such forcible responses beyond the realm of the jus ad bellum (e.g., by framing them as a form of "law enforcement"). Those adopting a broader reading of Article 2(4) seek the legal basis within the regime on the use of force, whether by construing them as a form of "on-the-spot reaction" in self-defense or as a separate customary law exception to the prohibition on the use of force.

${ }^{5} \underline{\text { SC Res. } 573}$ (Oct. 4, 1985).

${ }^{6}$ Nils Melzer, TARgeted Killing In International LaW 51 (2008). 
O'Connell belongs to the former category. In particular, she cites two legal bases. First, she suggests that states can respond to minor uses of armed force "with a minor use of armed force under the law of countermeasures." Yet, the position that lawful countermeasures can involve (minor) use of armed force goes against the view of the International Law Commission, of the arbitral tribunal in the Guyana/Suriname case, and against the view of a clear majority in legal doctrine (including, for that matter, Olivier Corten). Second, O'Connell refers to the possibility of personal/individual self-defense of military personnel, which is "part and parcel of the human right to life." But can it seriously be argued that when a hostile confrontation takes place between two military vessels over the high seas, or two military aircraft, this is simply a matter of balancing the right to life of the individual crew-members, governed solely by national criminal law and human rights law? I find this argument unpersuasive, in part because such incident prima facie affects the "international relations" between the states concerned in the sense of Article 2(4), and brings into play the rights and obligations of these states themselves (and not just those of the individual crew-members).

In the end, it seems that the legal basis for small-scale forcible responses cannot be found outside of the jus ad bellum. The better legal argument is, in my view, based on the concept of "on-the-spot reaction"- -and, yes, I do see this as part and parcel of the (international) right of self-defense. Contrary to what O'Connell's suggests, however, this concept is not something completely novel, nor does it imply a radical loosening of the criteria for self-defense. It is worth observing, for instance, that this concept-developed primarily by Dinstein - is actually adopted by the Independent International Mission on the Conflict in Georgia in its (rigorous and balanced) report ${ }^{7}$ — which O'Connell also relies upon. Consider the following passage: "To the extent that the attacks on Georgian villages, police and peacekeepers were conducted by South Ossetian militia, self-defense in the form of on-the-spot reactions by Georgian troops was necessary and proportionate and thus justified under international law." 8 Moreover, the concept does not imply a radical loosening of the criteria of self-defense. The Georgia report explains that on-the-spot reaction in self-defense relates to the "employment of counter-force by those under attack or present nearby." It must be distinguished in this context from exercises of self-defense that involve "the entire military structure." On-the-spot reaction indeed presupposes a particularly strict reading of the necessity and proportionality criteria. Again, O'Connell's views on the situations where states may lawfully resort to armed force may be far less removed from those of the present author than she wishes to believe-although there is certainly a conceptual divide.

\section{Final Remark}

Finally, I read with some surprise Mary Ellen O'Connell's claim that my book on armed attack was the product of my "interest in expanding the right to resort to force in self-defense." O'Connell regrets that the AJIL piece does not cite the most important piece of State practice, viz. the 2005 UN World Summit Outcome, where States confirmed that the Charter rules on the use of force were adequate and need not be amended. She stresses that, rather than questioning the current legal regime on the use of force, we should focus on improving compliance, rather than with introducing greater flexibility and expanded rights to resort to force. I respectfully invite O'Connell to reread (or read) the conclusion of my book (or Corten's review ${ }^{10}$

72 REPORT ON THE INDEPENDENT INTERNATIONAL FACT-FINDING MiSSION ON THE CONFLICT IN GEORGIA (2009).

${ }^{8} \underline{I d}$. at 251 .

${ }^{9} \underline{I d}$. at 249 .

10 Olivier Corten, Review of TOM RuYs, 'ARMED ATTACK' AND ARTiCle 51 OF THE UN CHARTER: Evolutions IN CUSTOMARY LAW AND PRACTICE (2013). 
thereof). The final section of the conclusion ${ }^{11}$ is concerned specifically with the need to strengthen the compliance pull of the jus ad bellum regime. The final paragraphs read as follows:

Claims that the Charter regime on the use of force is fundamentally maladjusted to current security needs are grossly exaggerated. Admittedly, there is a need for a cautious revision of the applicability of self-defense to attacks by non-state actors, and, above all, a need for clarification and reaffirmation of the Charter norms. Yet, as the international community of states acknowledged in September 2005, the relevant provisions of the United Nations Charter remain in essence adequate to address the full range of threats to international peace and security. ${ }^{12}$

Again, contrary to what O'Connell believes, the aim of the article in the Journal is not to expand the right to resort to force in self-defense. Its purpose is rather to conceptually clarify the meaning of "force" (an endeavor that ought to contribute to the compliance pull of the normative framework) and to signal the trap created by the acceptance of a de minimis threshold for UN Charter 2(4). It follows that O'Connell's critique at the address of the Journal coeditors-in-chief - that, for the fourth time in four years, the Journal has selected a major article concerned with expanding the right to resort to armed force-would seem ill-guided.

11 See RUYS, supra note 32 at 545-50.

${ }^{12} \underline{I d}$. at 550 . 